\title{
Research for the conservation of cultural heritage in the context of the circular economy
}

DOI: 10.35530/IT.072.01.1807

\author{
DORINA CAMELIA ILIES \\ MIHAELA CRISTINA LITE \\ LILIANA INDRIE \\ FLORIN MARCU \\ CĂLIN MOȘ \\ MĂDĂLINA ROPA \\ BOGDAN STURZU
}

MONICA COSTEA

ADINA VICTORIA ALBU

PAUL SZABO-ALEXI

ALPHONSE SAMBOU

GRIGORE VASILE HERMAN

TUDOR CACIORA

NICOLAIE HODOR

\begin{abstract}
REZUMAT
Research for the conservation of cultural heritage in the context of the circular economy

The heritage woven objects could be analyzed for defects hidden to the naked eye using non-invasive and non-destructive ultrasonography techniques. Ultrasonography is able to offer information about altered areas, such as gasps, interruptions, discontinuances, narrowed areas, fiber breaks, different densities of the material, defects caused by natural or anthropic factors: improper storage and exposure conditions, the presence of microorganisms and traces of their activity, mechanical causes etc. By recycling of the cotton fibers from other decrepit materials, which are not directly usable, the recondition and rendition of the national and world cultural heritage of these refurbished objects would be accomplished. The impact on the environment is diminished compared to the case when new cotton fibers are created.
\end{abstract}

Keywords: cultural heritage, ultrasonography, recycling, circular economy

Investigații privind conservarea patrimoniului cultural în contextul economiei circulare

Textilele de patrimoniu ar putea fi analizate în ceea ce privește unele defecte care nu pot fi văzute cu ochiul liber, prin folosirea tehnicilor de ultrasonografie non-invazive și non-destructive. Ultrasonografia este capabilă să ofere informații despre zonele modificate, precum adâncituri, întreruperi, discontinuități, zone înguste, rupturi de fibre, diferite densități ale materialului, defecte cauzate de factori naturali sau antropici: condiții de depozitare și expunere necorespunzătoare, prezența microorganismelor și urme ale activității lor, cauze mecanice etc. Prin reciclarea fibrelor de bumbac din alte materiale uzate, care nu sunt direct utilizabile, s-ar putea realiza recondiționarea articolelor deteriorate, obiectele recondiționate putând fi redate patrimoniului cultural național și mondial. Impactul asupra mediului este diminuat în comparație cu cazul în care sunt create noi fibre de bumbac.

Cuvinte-cheie: patrimoniu, ultrasonografie, reciclare, economie circulară

\section{INTRODUCTION}

When thinking about the textile industry for the past century, it should be mentioned that most of the garments have been reused and recycled, as the technological process to obtain them was difficult and time consuming, but the materials were of natural provenance. In this manner, the impact over the environment was minimum, natural materials decomposed easily and there were no questions if the natural resources would be exhausted although the society was intensively using them. Amid the aggressive promotion of the consumer society, the world is currently witnessing, the increase of the moral perishability process of textile products, despite the fact that physically and functional they meet all the requirements. Scientists figured out that a linear economy is no longer sustainable for the society and the circular economy flourished, proving real benefits both for now and for the future. Nevertheless, in the last few years, due to a growing awareness of the environmental issues, there has been a considerable interest in repair, maintenance, recycling and regeneration of the products. Some designers and producers have adopted techniques such as refurbishment, restyling and clothing redesigning, additional decorations and overlapping, patchworks, in order to restore used fabrics, increasing its value and delaying the removal from the landfill of waste. The study case is represented by an element of textile heritage, respectively an embroidered peasant blouse ("ie") around 100 years old from Bihor County, Romania (figure 1). The embroidered peasant blouse ("IA"), part of the cultural heritage, represents an essential clothing component of the Romanian folk costume, incorporating a multitude of defying aspects for the specific identity of the local, especially rural, respectively of the geographical and historical space where it 


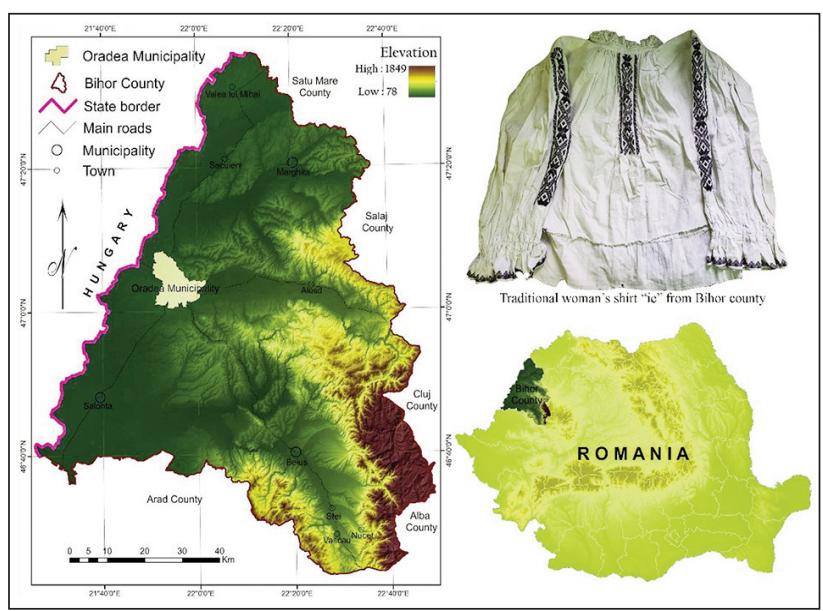

Fig. 1. The geographical location of the area of origin of the traditional women's shirt "ie"

appeared and evolved [1, 2]. There has been a while when, either from ignorance or carelessness, the embroidered peasant blouses were thrown away to the garbage can, as they were not "fashionable anymore". The disappearance of the custom of wearing embroidered peasant blouses represents a dramatic period for the Romanian traditional art. The major fashion houses started to be inspired by the patterns and motifs sewn once on the traditional costumes, including the Romanian ones. In the last few years, the embroidered peasant blouses have experienced a delightful come back. Famous designers have brought on the fashion catwalk the Romanian embroidered peasant blouse. Once returned" in trends", the famous blouse of the traditional folk costume gained the attention of the Romanian women as well. The embroidered peasant blouses started to be reused, to be reconditioned, even workshops were created where women are learning how to create an embroidered peasant blouse. The old embroidered peasant blouses are different from the ones that are now being worked in series to be marketed, because they are made of cotton cloth different in texture from the present ones. For the assessment of the fibrillary structure of the fabric's identification of visible and less visible defects on naked eye of the textile materials, the use of high ultrasonography has been tried. Common in medicine, it can also contribute to the analysis of other structures that can be penetrated by ultrasounds. Modern ultrasounds are equipped with high resolution (high frequency) suitable to qualitative analysis of superficial structures, such as fabrics. The extremely high resolution of the obtained images gives the possibility of a fine analysis of the structure of the yarns of a woven material.

\section{CASE STUDY}

\section{Literature review}

The circular economy proposes a different approach based on the reuse and recycling of the goods instead of disposing them as soon as there are no longer useful [3,4]. There is a major link between circular economy and sustainable development as circular economy embraces the principles of sustainable development, having its starting point in the Agenda [4, 5]. Mostly CE it is referred as cyclical closed - loop system which could solve the linear economy environmental issues [6, 7]. The interest for the circular economy is high among scholars from different domains due to the benefits it brings to the modern society and the perspective for the future [8]. Large sports equipment companies have started using recycling since 2010 to create highly performing sports equipment with the least impact on the environment $[9,10]$.

The purpose of the present study is to highlight new methods and techniques for investigating some elements of textile heritage for the assessments of their condition, conservation and reconditioning, in the context of imposing a new conceptual approach to the circular economy, focused on volume reduction of waste, recycling and reuse [11-21]. The present study is a continuation of others scientific approaches that had as subject different elements of textile heritage [22-29].

\section{Method}

X-radiography tools used for textile contributes to a good documentation for a better condition assessment and for the preserving of the objects, being a non-invasive and non-destructive technique; the analysis and interpretation of the obtained images highlight certain details and the hidden characters of the textile material, the techniques of sewing and weaving, repair, use, patterns of decay and dating, through digital image manipulation and interpretation [30]. Such techniques have been successfully used in the analysis of textile on the mummies in Peru, within the Peruvian Institute of Bioanthropology [31], Utrcht Museum being a pioneer in introducing the public in the use of X-rays in research [31]. As an objective method of analyzing the integrity of the fabric we used ultrasonography, a Samsung RS 80 (Samsung Healthcare Ultrasound) device, equipped with high resolution linear probes: L3-12A probe, with variable frequency up to $12 \mathrm{MHz}$, respectively LA4$18 \mathrm{~B}$ probe, with variable frequency up to $18 \mathrm{MHz}$.

\section{Results and discussions}

At a frequency of 15-18 MHz, high-frequency ultrasonography achieves an axial resolution (the possibility to distinguish two points perpendicular to the plane of the ultrasound waves) of $100 \mu \mathrm{m} /$ pixel and a lateral resolution (the possibility to distinguish two points in the plane parallel to the ultrasound waves) of $90 \mu \mathrm{m} /$ pixel, which can be used to differentiate certain lesions and interruptions in mass of material larger than $0.1 \mathrm{~mm}$ [32].

The study object is an embroidered peasant blouse around 100 years old from Bihor County, Romania (figure 1). The aim was to identify on the ultrasound images the interrupted, thin threads or the presence of larger defects inside the fabric, the lack of homogeneity of the material and respectively the presence 

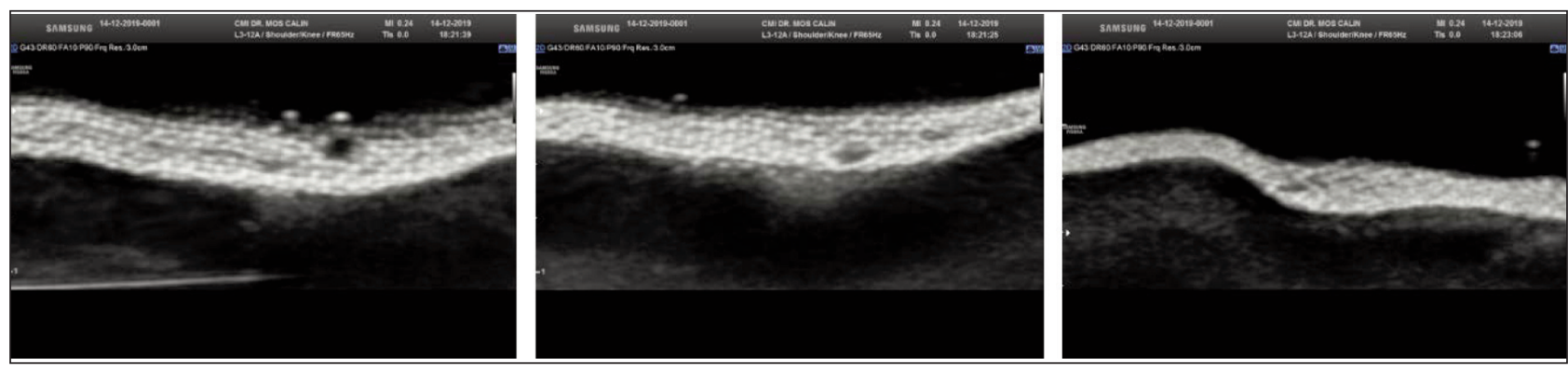

Fig. 2. Clinical echography images of the fabric of the traditional shirt ("ie")

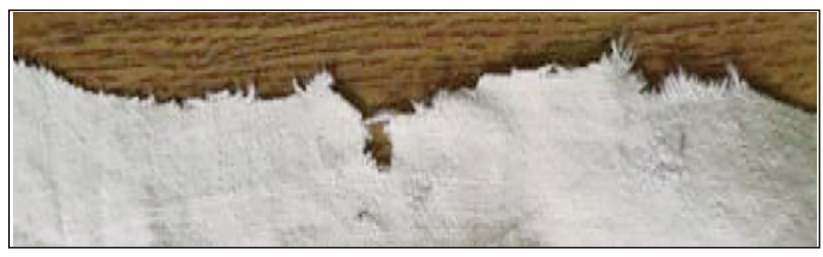

Fig. 3. Photo of deteriorated fabric of traditional shirt ("ie")

of several gaps in its mass (figures 2 and 3 ). It is possible to identify and interpret, monitor and map the degraded and vulnerable areas, where the density of the material is different from the average, where there are gaps in the mass of the material, broken, broken or thinned fibers, etc. In the future, an objective method of analysis will be refined regarding the examination protocol: choosing the place where the examination will be carried out; the surface of the fabric examined; meticulous identification and quantification of defects identified in the field and use of statistical methods.

The cotton material of the embroidered peasant blouse could be reconditioned on the areas thus identified and which requires it, with the use of a similar or even identical raw material by recycling/regenerating the cotton yarns from other materials, not recoverable for direct use [33, 34].

\section{CONCLUSIONS}

The circular economy proposes a different approach based on the reuse and recycling of the goods instead of disposing them as soon as there are no longer useful so that the impact on the environment is greatly diminished. This is successfully implemented by the major fashion houses in the world, but also in the field of high-performance sports. The non-invasive and non-destructive technique of monitoring and interpreting the images obtained by ultrasonography (including textile materials) has proved very useful in evaluating the state of the objects, identifying, quantifying, interpreting material defects (gaps, broken fibers, thinned etc.) for good preservation by recycling/regenerating textile fibers from other end-of-life materials, but which can be used successfully for reconditioning and reinvents the materials for future generations.

\section{ACKNOWLEDGEMENTS}

The research was possible by equal scientific involvement of all authors. The authors wish to thank to anonymous reviewer for their thoughtful suggestions and comments and to acknowledge the support of the Grant PN-III-P1-1.2PCCDI-2017-0686.

\section{REFERENCES}

[1] Gutarowska, B., Pietrzak, K., Machnowski, W., Milczarek, J.M., Historical textiles - a review of microbial deterioration analysis and disinfection methods, In: Textile Research Journal, 2016, 87, 19, 2388-2406

[2] Kumar, R.A., Sathya, R.I., Importance of digitization process in textiles, In: International Journal of Innovative Research in Computer and Communication Engineering, 2015, 3, 7, 7011-7015

[3] Patrizia, G., Ulgiati, S., Managing the transition to the circular economy, Part VI draft chapter, 2015, Available at: https://www.researchgate.net/publication/335475059_Managing_the_transition_to_the_circular_economy [Accessed on January 31, 2020]

[4] Cepolina, S.E., Textile and clothing industry: an approach towards sustainable life cycle production, In: International Journal of Trade, Economics and Finance, 2022, 3, 1, 7-13

[5] Valavanidis, A., Concept and Practice of the Circular Economy. Turning goods at the end of their service life into resources, closing loops in industrial ecosystems and minimizing waste, Available at: https://www.researchgate. net/publication/326625684_Concept_and_Practice_of_the_Circular_Economy [Accessed on January 31, 2020]

[6] Murray, A., Skene, K., Haynes, K., The Circular Economy: An Interdisciplinary Exploration of the Concept and Application in a Global Context, In: Journal of Business Ethics, 2017, 140, 3, 369-380

[7] Alcayaga, A., Hansen, E.G., Smart Products as Enabler for Circular Business Models: the Case of B2B Textile Washing Services, $3^{\text {rd }}$ PLATE 2019 Conference, Berlin, Germany, 18-20 September 2019, Available at: 
https://www.researchgate.net/publication/336073114_Smart_Products_as_Enabler_for_Circular_Business_Model s_the_Case_of_B2B_Textile_Washing_Services [Accessed on January 31, 2020]

[8] Wilson, L., The sustainable future of the Scottish textiles sector: challenges and opportunities of introducing a circular economy model, In: Textiles and Clothing Sustainability, 2015, 1, 1, 5

[9] Nike News, Nike's Football Kits are Made of Recycled Plastic Bottles, 2018, Available at: https://news.nike.com/ news/sustainability-football-kits [Accessed on January 31, 2020]

[10] Ling, K., Recycled Plastics Industry Scores 'Gooooal!' at World Cup, 2010, Available at: https://archive.nytimes. com/www.nytimes.com/gwire/2010/07/09/09greenwire-recycled-plastics-industry-scores-gooooal-at-w-42896.html [Accessed on January 31, 2020]

[11] United Nations, Transforming our world: The 2030 Agenda for Sustainable Development, 2015

[12] European Commission, COM 2014-398 final, Towards a circular economy: a zero waste program for Europe, Bruxelles, 2014

[13] European Commission, COM 2015-614 final, Closing the loop - an EU action plan for the circular economy, Bruxelles, 2015

[14] MacArthur Foundation, The concept of circular economy, regenerative economy, 2010, Available at: https://www.ellenmacarthurfoundation.org/circular-economy/concept [Accessed on January 31, 2020]

[15] MacArthur Foundation, Towards a circular economy: business rationale for an accelerated transition, 2015, Available at: https://www.ellenmacarthurfoundation.org/assets/downloads/TCE_Ellen-MacArthur-Foundation-9Dec-2015.pdf [Accessed on January 31, 2020]

[16] Popescu, D.I., Social Responsibility and Business Ethics: VII. Circular Economy and the Role of Corporate Social Marketing, In: Calitatea, 2018, 19, 163, 118-121

[17] De Wit, M., Hoogzaad, J., Ramkumar, S., Friedl, H., Douma, A., The Circularity Gap Report: An analysis of the circular state of the global economy, In: Circle Economy: Amsterdam, The Netherlands, 2018

[18] Moraga, G., Huysveld, S., Mathieux, F., Blengini, G. A., Alaerts, L., Van Acker, K., Dewulf, J., Circular economy indicators: What do they measure?, In: Resources, Conservation and Recycling, 2019, 146, 452-461

[19] Păcurariu, R.L., Nan, L.M., Bîrgovan, L.A., David, M., Geanina, C., Implementarea economiei circulare în industria textilă, In: Review of Management \& Economic Engineering, 2019, 18, 4

[20] Hartley, K., van Santen, R., Kirchherr, J., Policies for transitioning towards a circular economy: Expectations from the European Union (EU), In: Resources, Conservation and Recycling, 2020, 155, 104634

[21] Migliore, M., Oberti, I., Talamo, C., Circular Economy and Recycling of Pre-consumer Scraps in the Construction Sector. Cross-Sectoral Exchange Strategies for the Production of Eco-Innovative Building Products, In: Regeneration of the Built Environment from a Circular Economy Perspective, Springer, Cham, 2020, 217-228

[22] Ilieș, D.C., Oneț, A., Wendt, J. A., Ilieş, M., Timar, A., Ilieș, A., Herman, G. V., Study on microbial and fungal contamination of air and wooden surfaces inside of a historical Church from Romania, In: Journal of Environmental Biology, 2018, 39, 6, 980-984

[23] Ilieș, D.C., Onet, A., Marcu, F., Gaceu, O., Timar, A., Baias, S., Ilies, A., Herman, G.V., Costea, M., Tepelea, M., Josan, I., Wendt, J., Investigations on air quality in the historic wooden church in Oradea city, Romania, In: Environmental engineering and management journal, 2018, 17, 11, 2731-2739

[24] Ilieș, D.C., Indrie, L., Wendt, J., Ilieș, A., Gaceu, O., Demenchuk, E., Marcu, F., Burtă, L., Baidog, A., Albu, A., Herman, G.V., Axinte, A., SEM investigations on old maps with canvas support. In: Proceedings of the International Conference TexTeh IX. Advances textiles for a better world, 2019, ISSN 2068-9101, 153-157

[25] Ilieș, D.C., Oneț, A., Herman, G., Indrie, L., Ilieș, A., Burtă, L., Gaceu, O., Marcu, F., Baias, Ș., Caciora, T., Marcu, A.P., Oana, I., Costea, M., Ilieș, M., Wendt, J., Mihincău, D., Exploring the indoor environment of heritage buildings and its role in the conservation of valuable objects, In: Environmental Engineering and Management Journal, 2019, $18,12,2579-2586$

[26] Ilies, D.C., Herman, G.V., Caciora, T., Ilies, A., Indrie, L., Wendt, J., Axinte, A., Diombera, M., Lite, C., Berdenov, Z., Albu, A., Considerations Regarding the Research for the Conservation of Heritage Textiles in Romania, IntechOpen, Waste in Textile and Leather Sectors, 2020, 185-207, http://dx.doi.org/10.5772/intechopen.91393

[27] Ilieș, D.C., Indrie, L., Ilieș, A., Marcu, F., Axinte, A., Burtă, L., Herman, G.V., Atasoy, E., Baidog, A., lovan, C., Albu, A., Costea M. Wendt, J.A., Investigations of aged textiles using scanning electron microscopy, In: Journal of Environmental Biology, 2020, 41, 2, 99-504

[28] Marcu, F., Ilieș, D.C., Wendt, J., Indrie, L., Ilieș, A., Burta, L., Caciora, T., Herman, G.V., Todoran, A., Baias, S., Albu, A., Gozner, M., Investigations regarding the biodegradation of cultural heritage. Case study of traditional embroidered peasant shirt (Maramures, Romania), In: Biotehnological Letters, 2020, 25, 2, 1362-1368

[29] Oneț, A., Ilieș, D.C., Ilieș, A., Herman, G.V., Burtă, L., Marcu, F., Buhaș, R., Caciora, T., Baias, Ș., Oneț, C., Ilieș, M., Lincu, A., Indoor air quality assessment and its perception. Case study - historic wooden church, Romania, In: Romanian Biotechnological Letters, 2020, 3, 1547-1551

[30] Calvert, S., Power, J., Ryall, H., Bills, P., Reconstructing textile heritage, In: Journal of Writing in Creative Practice, $2014,7,3,415-425$ 
[31] O'Connor, S., Brooks, M., X-Radiography of Textiles, Dress and Related Objects, 2007, 359, Available at: https://www.researchgate.net/publication/38141670_X- [Accessed on January 31, 2020]

[32] Shung, K., Cannata, J., Zhou, M.Q., Lee, J.. High frequency ultrasound: A new frontier for ultrasound, In: Annual International Conference of the IEEE Engineering in Medicine and Biology Society, Minneapolis, USA, 2009

[33] Inferrera, A., Fibre tessili riciclate e rigenerate: é davvero moda etica sostenibile?, 2019, Available at: https://concosalometto.com/2019/01/29/fibre-tessili-riciclate-rigenerate-moda-etica-sostenibile [Accessed on January 31, 2020]

[34] Deac, L.A., Gozner, M., Sambou A., Ethnographic museums in the rural areas of Crișana region, Romania keepers of local heritage, tradition and lifestyle, In: GeoJournal of Tourism and Geosites, 2019, 27, 4, 1251-1260, http://doi.10.30892/gtg.27411-430

\section{Authors:}

DORINA CAMELIA ILIEȘ ${ }^{1}$, MIHAELA-CRISTINA LITE ${ }^{2,3}$, LILIANA INDRIE ${ }^{4}$, FLORIN MARCU ${ }^{5}$, CĂLIN MOȘ ${ }^{5}$, MĂDĂLINA ROPA ${ }^{6}$, BOGDAN STURZU1 ${ }^{1}$, MONICA COSTEA $^{7}$, ADINA VICTORIA ALBU ${ }^{4}$, PAUL SZABO-ALEXI ${ }^{1}$, ALPHONSE SAMBOU ${ }^{8}$, GRIGORE VASILE HERMAN ${ }^{1}$, TUDOR CACIORA ${ }^{1}$, NICOLAIE HODOR ${ }^{9}$

${ }^{1}$ University of Oradea, Faculty of Geography, Tourism and Sport, $1^{\text {st }}$ University Street, Oradea, 410087, Romania e-mail: iliesdorina@yahoo.com, bogdan_sturzu_laurentiu@yahoo.com, anamaria_lazuran@yahoo.com, pszabo@uoradea.ro,grigoreherman@yahoo.com

${ }^{2}$ National Research and Development Institute for Textiles and Leather, 16 Lucretiu Patrascanu street, 030508, Bucharest, Romania e-mail: cristina.lite@incdtp.ro

${ }^{3}$ Politehnica University of Bucharest, 1-7 Gheorghe Polizu street, 011061, Bucharest, Romania

${ }^{4}$ University of Oradea, Faculty of Energy Engineering and Industrial Management, Department of Textile, Leather and Industrial Management, 4 B.St. Delavrancea street, 410058, Oradea, Romania e-mail: liliindri@yahoo.com, adina_victoria@yahoo.com

5 University of Oradea, Faculty of Medicine and Pharmacy, Oradea, Romania e-mail: mfmihai27@yahoo.com,drmoscalin@yahoo.com

${ }^{6}$ National College „Avram lancu” Ștei, Bihor, Romania e-mail: madalinaropa@yahoo.com

${ }^{7}$ Faculty of Environmental Protection, University of Oradea, 26 Gen. Magheru street, 410048, Oradea, Romania e-mail: costea.monica@yahoo.it

8University of Ziguinchor, Training and Research Unit of Economic and Social Sciences, Department of Tourism, Senegal e-mail: asambou@univ-zig.sn

${ }^{9}$ Babes-Bolyai University, Faculty of Geography, 5-6 Clinicilor Street, Cluj Napoca, Romania e-mail: nicolaiehodor@ubbcluj.ro

\section{Corresponding author:}

TUDOR CACIORA

e-mail: tudor.caciora@yahoo.com 